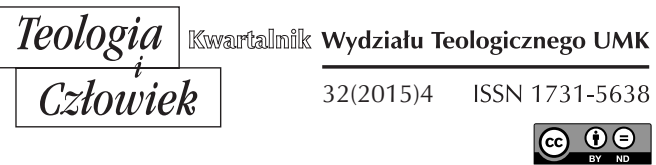

KS. DANIEL BRZEZIŃSKI*

PŁOCK-TORUŃ

\title{
THE NOTION OF MYTH IN HISTORY, ETHNOLOGY AND PHENOMENOLOGY OF RELIGION
}

DOI: http://dx.doi.org/10.12775/TiCz.2015.047

The term "myth" from the Greek word mythos which means "word" or "story" is usually associated with the unreal world. ${ }^{1}$ It is frequently understood as a tale or invented story which has nothing to do with reality and is solely perceived as a figment of human imagination. Unfortunately, such a narrow and limited perception of myth is responsible for the fact that great ancient mythologies (Roman, Greek, Egyptian, Assyrian or Hindu) are nowadays understood only as the exceptional poetic narrations

* Ks. Daniel Brzeziński - prezbiter diecezji płockiej; dr hab. nauk teologicznych; dr liturgiki; pracownik naukowy i senator Uniwersytetu Mikołaja Kopernika w Toruniu; profesor w Papieskim Instytucie Liturgicznym św. Anzelma w Rzymie; kustosz Kapituły Katedralnej Płockiej; przewodniczący Komisji Liturgicznej Diecezji Płockiej; wiceprezes toruńskiego oddziału Polskiego Towarzystwa Teologicznego; członek Towarzystwa Naukowego Płockiego i Towarzystwa Naukowego w Toruniu.

${ }^{1}$ This article is an adaptation of an earlier text by the author: D. Brzeziński, "Chrystus wczoraj i dziś i na wieki”. Anamnetyczny wymiar roku liturgicznego, Toruń 2010, pp. 75-90. 
with a great linguistic and cultural significance but deprived of any religious dimension which is worthy of attention.

However, ethnology, history and philosophy of religion explicitly reject such a concept and assessment of myths as for both a single homo religiosus and the entire community in which it has been created each myth has never been treated as a tale but something significant and real which constituted a fundamental moment of encounter with the supernatural world and with everything that transcends human nature. Certainly, objectively speaking, myth is not the truth in the way we understand it nowadays but this context is of secondary importance as those "untrue" myths are in fact true in a different sense. Myths have been created to give answer to the most basic questions concerning human existence. In this way we should understand each mythology and religion. Myth, conceived as an attempt to understand man and the world, is a crucial ingredient of all cults including such historical religions as Judaism and Christianity although the role of it in those religions is diametrically different from the so-called "natural" religions. ${ }^{2}$

Myth is not linked only with polytheism. As a literary genre myth is present in Holy Scripture, especially in the Old Testament. ${ }^{3}$ In Judaism and Christianity myth is a literary device in which, when speaking about God, a sign/symbol plays the same role as abstract language in metaphysics and in which, according to Pierre Grelot ( $† 2009)$, "relations between God and man are the subject of dramatic staging."4 Grelot claims that myth is a literary genre like others which possesses its own truth and is not unworthy of the word of God because under the cover of symbol it

${ }^{2}$ Cf. B. Mondin, Mito e religioni. Introduzione alla mitologia religiosa e alle nuove religioni, Milano 1997, pp. 7-8. On various aspects of myth see: R. Marlé, Mythe, [in:] L. Pirot, A. Robert, H. Cazelles et al. (Eds.), Dictionaire de la Bible - Supplement, vol. 6, Paris 1960, pp. 225-268; G. Betori, Mito, [in:] P. Rossano, G.F. Ravasi, A. Girlanda (Eds.), Nuovo Dizionario di Teologia Biblica, Cinisello Balsamo 1988, pp. 993-1012; J. Vidal, Mito, [in:] P. Poupard (Ed.), Grande Dizionario delle Religioni, vol. 2, Assisi-Casale Monferrato 1988, pp. 1380-1386; K. W. Bolle, P. Ricoeur, Mito, [in:] M. Eliade et al. (Ed.), Enciclopedia delle Religioni, Milano 1993, pp. 359-381.

3 See J.S. Synowiec, Gatunki literackie w Starym Testamencie, Kraków 2003, pp. 243-251.

\footnotetext{
${ }^{4}$ Cf. P. Grelot, La Bible parole de Dieu, Paris 1965, p. 125.
} 
suggests content which cannot be clearly expressed when using abstract language. ${ }^{5}$

The Old Testament knows only such myths (in a positive meaning of this word) in which either God acts Himself or a related event happens between God and people. The most interesting examples of myths in the Old Testament are undoubtedly long narratives from the Book of Genesis about the Creation and the Fall (Gen 2:4b-3:24) about the Deluge (Gen 6:1-9:17) and the construction of the Tower of Babel and city (Gen $11: 1-9){ }^{6}$

Bronisław Malinowski ( $\uparrow 1942)$ who belongs in the pantheon of the greatest sociologists, ethnologists and culture historians, the creator of functionalism in anthropology of culture wrote that myth, "clothing the brutal and naked beauty of primeval thought with the dignity of tradition and the majesty of sacredness, exerts a singular attraction upon the human mind, civilized and sophisticated, as well as simple and untutored. The mixture of incompatible extremes, of the shameful and the holy, the graceful and the raw, the fleshly and the spiritual, the tragic and the clownish, surrounds myth with an atmosphere of mystery and gives it a meaning which has always inspired the artist and puzzled the student. From myth and folk tale have sprung the earliest as well as the ripest products of art: the savage enactment of myth at initiation or tribal feast as well as the tragedies of ancient Greece, the Elizabethan theatre, and the Wagnerian musical drama. In primitive, in pagan, and in Christian painting and sculpture, myth has supplied most of the subject matter and atmosphere."

Western civilization got acquainted with myth through Greek mythology which has been for ages an unsurpassed model of multilayered and interconnected system of tales, referring to "what happened"

5 Cf. ibid., p. 2.

${ }^{6}$ Underlined themes of myths in the Bible are widely discussed in Polish sources concerning the subject, see J. Kudasiewicz, Biblia. Historia. Nauka. Rozważania i dyskusje biblijne, Kraków 1986, pp. 203-223; E. Bulanda, "Geneza i znaczenie mitu w historii literatury”, Ruch Biblijny i Liturgiczny 12 (1959) No. 4, pp. 373-396 and No. 5, pp. 443-472; T. Jelonek, "Historia - mit - teologia", Polonia Sacra 19 (1997) No. 1/45, pp. 79-93.

7 Cf. B. Malinowski, O studiach mitologicznych, [in:] B. Malinowski, Mit, magia, religia, trans. B. Leś, D. Praszałowicz, Warszawa 1990 (Dzieła, vol. 7), p. 140. 
and literary works based on them, such as Iliad or Sophocles' (†406 BC), Euripides' ( $\uparrow 407 / 406$ BC) and Aeschylus' ( $\uparrow 456$ BC) dramas, became an excellent product of ancient minds and the first source of literature which everyone should know. The basic problem is to define the phenomenon of myth which possesses multiple meanings and functions and similarly to religion escapes clear and unequivocal academic definitions. ${ }^{8}$

Research demonstrates that general terms which are the subject of reflection by various areas of humanities cannot be defined in an unquestionable manner and myth belongs to them. Even S. Thompson $(\dagger 1976)$ in his textbook of folkloristics, ${ }^{9}$ L. Honko (†2002) in his text devoted to the problem of defining myth ${ }^{10}$ or W.G. Doty in the second edition of his study ${ }^{11}$ demonstrate the helplessness of researchers when dealing with a broad semantic field of this term. I. Strensky and R. Wagner show that definitions coming from various researchers include opposing terms: true - false, revelation - illusion, sacrum - profanum, real fantastic, historical - ahistorical, symbol - sign, archetype - stereotype, logical - prelogical, intellectual - emotional, traditional - modern. ${ }^{12}$

The most general definitions of myth refer to its narrative character informing that myth is a sacral story, namely a sacred tale about primeval times. According to M.J. Herskovits ( $† 1963)$, this narrative gives a symbolic expression to a system of relationships between man and the universe. It always expresses some aspect of a cosmic order. ${ }^{13}$

The term "myth" may be understood in at least three different ways. In a narrow sense, most frequently encountered in ethnology, folkloristics and literary theory, "myth" is simply a tale. As such it does

${ }^{8}$ Cf. A. Szyjewski, Etnologia religii, Kraków 2008, p. 78.

9 See S. Thompson, The Folktale, Berkeley 1977, p. 9.

${ }^{10}$ See L. Honko, “The Problem of Defining Myth", [in:] H. Biezais (Ed.), The Myth of the State, Stockholm 1972 (Scripta Instituti Donneriani Aboensis, vol. 6), pp. 7-19; L. Honko, "Der Mythos in der Religionswissenschaft", Temenos 6 (1970), pp. 36-67.

11 See W.G. Doty, Mythography. The Study of Myths and Rituals, London 2000.

12 See I. Strensky, Four Theories of Myth in Twentieth-Century History: Cassirer, Eliade, Lévi-Strauss and Malinowski, Iowa 1987, p. 1; R. Wagner, Lethal Speech. Daribi Myth as Symbolic Obviation, London 1978, p. 251.

${ }^{13}$ See M.J. Herskovits, Dahomean Narrative. A Cross-Cultural Analysis, Evanston 1958, p. 81. 
not differ qualitatively from other literary genres and its characteristics are its etiological nature, time of events which take place, characters who act as supernatural beings, such as gods and heroes, and human and cosmic scale of mythical events and their results. The second meaning of myth is an archaic world-view. Without losing its form, which is a narrative, i.e. the content expressed explicite, it constitutes the most direct expression of the so-called mythology implicite (expressed in rituals, figurative and symbolic art and also in space organisation). In this sense, mythology is a way of imagining the world which is present in traditional and early historic cultures until the late Middle Ages. Finally, in the general sense myth might be understood as a universal form of consciousness. In this perspective, which is represented by R. Barthes ( $† 1980)$, a French literary theorist, philosopher and semiotician, mythical thinking has dominated not only in prehistoric cultures but also is present in all human culture, both in thinking and consciousness of modern man. It is present in the mechanisms of association based on symbols and on collective conviction about the truth of myths as well as on human behaviour which is a "plate" of mythical patterns. ${ }^{14}$ In this article, psychological interpretation of myth which focuses on a linguistic objectivisation of mental fact and was proposed by, among others, C.G. Jung ( $† 1961)$, the creator of the so-called depth psychology, will be left out due to thematic limitations of the text.

Geoffrey S. Kirk (†2003) an eminent classical scholar known for his expertise in ancient culture and mythology stated that there is no single universal definition of myth. Myths in different cultures, communities and parts of the world differ significantly in their morphology and social functions. According to Kirk, it is better to start with a "traditional narrative" 15 when defining a myth.

In Polish literature an attempt to define a myth in its eclectic nature, as A. Szyjewski ${ }^{16}$ assesses it, was undertaken by E. Nowicka-

14 See R. Tomicki, Mit, [in:] Z. Staszczak (Ed.), Słownik etnologiczny. Terminy ogólne, Warszawa-Poznań 1987, pp. 244-248.

${ }^{15}$ His observations and experiences are included in the academic study about the nature of myth: G.S. Kirk, Myth, Its Meaning and Functions in Ancient and Other Cultures, Berkeley 1970; see: F. Stolz, Mit/Mitologia, trans. E. Perczak, [in:] H. Waldenfels (Ed.), Leksykon religii. Zjawiska - dzieje - idee, ed. by P. Pachciarek, Warszawa 1997, p. 263.

${ }^{16}$ See A. Szyjewski, Etnologia, pp. 79-80. 
Rusek. According to her, myth is a narrative tale which uses symbols and images ignoring the rules of formal logic which is absolutely true for both listeners and tellers. Myth is literal and possesses a specific sense of time and space, deals with themes of great importance, both subjective and objective, for an individual and community, ignoring the problems of strange communities. Myth understood in this manner in its pure form appears in the society defined as sacral and in culture of developed societies possesses its analogies, the nearest one being ideology. ${ }^{17}$

Greek term mythos initially denoted "something told" or a "story", "speech" and "word" and semantically did not differ much from logos. Mythos and logos were two related Greek terms. They both described a spoken word or, broadly speaking, a narrative. However, even in Antiquity the difference in meaning between them was underlined and in the Modern Age this difference has a fundamental importance. Myth as a story has acquired a connotation of tale and fiction, while logos denoted fact. Myth has remained in the sphere of narrative, while discursive thinking has become more important for logos, which analyses things and reaches their essence. ${ }^{18}$

A thorough and precise understanding of myths and the attitude to them of ancient Greeks and Romans is an extremely difficult question to establish. Furthermore, it is important to take into consideration that myths were varied and were created, even in Greece, in communities which differed from each other in terms of culture and religion. Even the same myth frequently functioned in several versions. Many myths had essential relationship with a religious sphere of human existence. There were also such which were described as "sacred tales" (hieroi logoi). They were passed on by the priests of certain centre of cult where mysteries took place. Their aim was to explain the meaning of rites, especially rites of initiation. ${ }^{19}$

Thus "what is myth?", asks M. Eliade (†1986), one of the greatest historians of religion and religion experts, and answers that in the

${ }^{17}$ Cf. E. Nowicka, "Sporne problemy w badaniach nad mitem", Kultura i społeczeństwo 3 (1984), pp. 29-42.

18 See F. Stolz, Mit/Mitologia, p. 265.

${ }^{19}$ Cf. B. Bravo, E. Wipszycka, Historia starożytnych Greków, vol. 1: Do końca wojen perskich, Warszawa 1988, p. 309. 
colloquial language of the $19^{\text {th }}$ century myth denoted everything that defied "reality". The creation of Adam, invisible man, history of the world told by the Zulu or The Theogony of Hesiod were myths. ${ }^{20}$ Fortunately, as Eliade observes, ethnological research forced us to return to the "semantic heritage" of primordial peoples and their archaic cultures. We somehow begin again to learn and understand the value of myth which has been developed by primordial communities. Myth has constituted and still is for those archaic cultures, which survived in some form, a cultural foundation and basis of social life. ${ }^{21}$ The concept of myth as an imperfect form of thinking which originates from the $19^{\text {th }}$ century propagated the view that myth attempts to express the knowledge about the world but it can be done only in a metaphorical and imperfect manner. ${ }^{22}$

Throughout the ages the understanding of the term "myth" has evolved, taking various forms, in both the ancient world and Christian culture. The original and basic meaning of the term "myth" is perfectly expressed in Homer's works ( $8^{\text {th }}$ century $\mathrm{BC}$ ): everything that is said, every human speech whether true or false is mythos. A Greek form of the verb "speak" or "tell" is mytheuo/mytheomai. Its meaning is very close to lego (speak), in the same way as a noun mythos is similar to logos. The terms logos and legein were used by Herodotus ( $\dagger$ ca. $425 \mathrm{BC}$ ) when he presented various narratives about gods and heroes, also those he did not believe in.

Since the times of Xenophanes of Colophon ( $\dagger$ ca. 480-470 BC) who was the first one to criticise and reject mythical images about divinity proposed by Homer and Hesiod ( $7^{\text {th }}$ century BC) Greeks had gradually "purified" mythos from any religious and metaphysical meaning. In the times of Plato, namely in the $4^{\text {th }}$ century before our Christian era, there appeared a distinction in meaning between mythos and logos which juxtaposes fiction (mythos) and truth derived from reason (logos). A verb mythologein appeared at that time and denoted "relating myths" or "narrating poetic tales".

Thus the term "myth" in contrary to logos and history was meant to denote everything that "cannot exist in reality". On the other hand, it

\footnotetext{
${ }^{20}$ M. Eliade, Mity, sny i misteria, trans. K. Kocjan, Warszawa 1999, p. 15.

${ }^{21}$ Ibid.

${ }^{22}$ See F. Stolz, Mit/Mitologia, p. 263.
} 
should be remembered that Judeochristianity also rejected as a "lie" and "illusion" everything that was not confirmed and authenticated by the Old or New Testament. Unfortunately, such a perception of "myth" as "fiction" is still widespread in colloquial language instead of another perception of myth as a "living reality", i.e. the reality which attempts to find an answer to the fundamental existential issues and offers patterns of behaviour or even gives meaning and value to human life. It is worth realising that the knowledge about the structure and function of myths in traditional societies, as M. Eliade underlined, allows us not only to explain certain stages of development of human thought but also to understand one of the categories characteristic of modern societies. ${ }^{23}$

According to M. Eliade, every myth (a "living myth") tells a certain "sacred story" which refers to some "primordial event" which happened in the so-called "primordial Time" at the beginning of the world and human history. Myth indicates how a given reality came into existence thanks to the intervention of "supernatural beings." It refers not only to the whole universe and its elements but also to human behaviour. Myth is always a narrative about some "creation" and demonstrates how some reality came into existence. "Supernatural beings" take part in this "creation", the heroes of myths are supernatural beings who enter human world. Myth reveals their faculties of "creation" and their "sacred" nature or supernatural character of their works. It also passes down to posterity an account of sacral behaviour and supernatural powers of those beings. Myth is always regarded as a sacred story by a given community, i.e. a "true story" as it refers to facts. ${ }^{24}$

It is worth noticing that in the consciousness of a given community or a tribe there has always been a distinction between "true stories", which referred to the reality, and "false stories" which have been regarded as tales or legends by natives. "False stories" could be told anywhere and at any time, whereas living myths were recited only during a period of sacred time, (usually in autumn or winter and only at night). This custom has survived even among peoples who have passed beyond the archaic stage

${ }^{23}$ See M. Eliade, Aspekty mitu, trans. P. Mrówczyński, Warszawa 1998, pp. 7-8; W. Lengauer, Religijność starożytnych Greków, Warszawa 1994, pp. 20-21.

${ }^{24}$ Cf. M. Eliade, Aspekty mitu, pp. 11-12. 
of culture. Many sacred myths, mostly those which concerned cosmogony and initiation, were not told or celebrated (the essence of myths, as we may observe, was not only their recitation but also celebration) in the presence of women. ${ }^{25}$

A distinction between "true stories" and "false stories" is based on the fact that the former refer to gods and supernatural beings, whereas the latter to heroes and exceptional animals. However, both categories are united in the way that they do not refer to the everyday world. ${ }^{26}$

B. Malinowski expressed his views in the same vein as Eliade. He observes that the most important characteristics of myth is the fact that it testifies to the past truth, however, always present and vital for reality. For a native, myth is neither a fictional story nor an account of the ancient past; it proves the existence of important reality which is partly alive nowadays. ${ }^{27}$

Myths, as Eliade notes, narrate not only the origin of the World, of animals, of plants, and of man, but also all the primordial events in consequence of which man became what he is today - mortal (in some myths immortal), sexed, organized in a society, obliged to work in order to live, and working in accordance with certain rules. If the World exists, if man exists, it is because Supernatural Beings exercised creative powers in the „beginning." But after the cosmogony and the creation of man other events occurred, and man as he is today is the direct result of those mythical events, he is constituted by those events. He is mortal because something happened in illo tempore. If this "something" had not happened, man would be immortal. ${ }^{28}$

Modern history of religion and ethnology borrowed from historians and ancient philosophers this division into "mythical" and

${ }^{25}$ See ibid., pp. 14-15.

${ }^{26}$ See ibid., p. 16.

27 See B. Malinowski, Mit jako dramatyczna forma dogmatu, [in:] B. Malinowski, Mit, magia, religia, p. 359; W. Werner, Kult początków. Historyczne zmagania z czasem, religia i geneza, Poznań 2004, pp. 8-14.

${ }^{28}$ See M. Eliade, Aspekty, p. 17. It is worth noting that according to the same mythological key based on Malinowski's and Eliade's research A. Szyjewski presents the beliefs of Slavs in his study Religia Słowian, Kraków 2003. 
"true" statements, i.e. "verifiable". ${ }^{29}$ However, let us repeat it once again that for our historical and theological reflection at this point it is of no importance whether all characters and situations presented in mythological accounts are the creation of human spirit and mind and in this sense are objectively false. It should be underlined that for a religious man in a given community mythology is understood and lived through in the perspective of the real world and not the world of fantasy. Mythology explains and "validates" the existence of the world, man and society. This last statement is the main reason why a religious man considers his mythology as a true story which gives meaning to his action. ${ }^{30}$ In somewhat simplified terms, it might be stated that the "true" nature of myth is not based on its historiography but historiosophy.

Some scholars attempt to classify myths, dividing them into several basic categories. According to B. Mondin, a well-known Italian philosopher and theologian, cosmogonic myths explain the origin of the world, anthropogenic myths concern the beginnings of man in the world, etiologic ("model") myths encompass partly the two former categories asking about the causes and beginnings of human existence and describe human experiences, as well as activities and problems of human existence, such as pain, guilt, evil and death. Soteriological myths explain interventions of supernatural beings thanks to which "salvation" of man is possible and finally eschatological myths give an answer as to how at the end times the world destroyed by catastrophes will be renewed and the dead resurrected to the new life. ${ }^{31}$

In Polish literature this classification was done by, among others, W. Lengauer. ${ }^{32} \mathrm{He}$ divided myths into the following categories: myths of the beginning (cosmogonic), myths about the origin of gods (theogonic), myths about the deeds of gods (the author calls them theological myths) and heroic myths which concern human history and its heroes. These categories, as Lengauer observes, "overlap". A cosmogonic myth is also theogonic and possesses the characteristics of a theological myth. These

\footnotetext{
${ }^{29}$ Cf. B. Bravo, E. Wipszycka, Historia, pp. 309-311.

${ }^{30}$ Cf. B. Mondin, Mito e religioni, p. 23.

${ }^{31}$ Cf. ibid., pp. 21-22.

${ }^{32}$ See W. Lengauer, Religijność, pp. 18-19.
} 
elements might be found even in heroic myths because the fate of heroes is linked with the fate of gods. At the same time, myths tell us a great deal about man: his situation in the world, his condition, nature and destiny. If myths are sui generis theology of ancient Greeks (this term borrowed from Greek is used by W. Lengauer as "Greek knowledge about gods") do they contain Greek anthropology? Can we distinguish apart from theological myth, an anthropological one? All myths, states Lengauer, are for people even if they narrate the story about gods or the creation of the world they serve people as they explain the world for them. ${ }^{33}$ Lengauer devotes much attention to etiological myths which explain, as it has been mentioned, the origin and justify the existence of human institutions, such as the state and society, or a feast, ritual and sacrifice. ${ }^{34}$

According to J. Campbell ( $† 1987)$ who, as is commonly assumed, revolutionised the notion of myth in modern social sciences myths fulfil four functions. ${ }^{35}$ First is the mystical function. Myth opens up the world and man to mystery. Man, in turn, realising himself the mystery of being and the whole universe experiences fear towards mysterium tremendum et fascinans, to use R. Otto ( $\dagger 1937)$ term. According to I.G. Barbour, in human life myths are the expression of salvific power which overcomes obstacles and restores the perfect state prior to the fall. This power may also take a personal form of some saviour, it might be also a rule, rite, or taboo to observe, etc. ${ }^{36}$ The second function of myth is cosmological. Myths "provide" with an image of basic structures of reality. Through constant repetition and justification of the order of the universe myths show its shape and mystical dimension. This repetitive character of myths is emphasised by, among others, G. van der Leeuv (†1950) who

${ }^{33}$ Ibid., p. 19. It should be noted that ancient Greek was familiar with and used the term theologia almost in the same sense as nowadays; however, it lacked the term anthropologia in a contemporary meaning. The verb anthropogein which exists in classical Greek denotes "to present in a human form".

${ }^{34}$ See ibid., p. 20.

35 See J. Campbell, Ekologia człowieka, trans. M.A. Bitner, Warszawa 1995; A. Szyjewski, Etnologia, pp. 88-89.

${ }^{36}$ Cf. I.G. Barbour, Mity, modele, paradygmaty. Studium porównawcze nauk przyrodniczych i religii, trans. M. Krośniak, Kraków 1984, p. 30. 
sees the essence of myth in the fact that it is continually repeated. ${ }^{37}$ The third function of myth is sociological which is to validate and maintain a certain sociological order. Myths act in favour of cultural stability, stimulate to action and provide with patterns of behaviour. Thus, it is said that a sociological function of myths implies certain ethical norms of a given individual and community. Finally, myths fulfil pedagogical function providing man with knowledge about himself and others. They demonstrate how to live with integrity in all circumstances. Man referring to his ancestors and preserving "mythical memory" derives from their lives wisdom which applies to his life in perspective of his own destiny. Some authors add to those four functions of myth others, for example explicatory, speculative or entertaining functions. ${ }^{38}$

No myth might be understood differently than as a vital cultural power. Thus no researcher can collect and analyse myths out of context. They must notice the influence of myth on social life, morality, law and also religious life with its entire rituals. ${ }^{39}$

Many researchers demonstrate permanence of myths in every culture both in literary culture of literate Greek and Roman societies and in exclusively oral tradition of illiterate primeval communities. The phenomenon of permanence of myth might be explained by its special function and meaning. It is also not difficult to notice the relationship between myth and ritual in almost all cases. ${ }^{40}$

This last statement also refers, taking into consideration all ontic differences and proportions, to Christianity. Without the presented concept of "myth" it is impossible to understand Christian liturgy and contemporary

${ }^{37}$ Cf. G. van der Leeuw, Fenomenologia religii, trans. J. Prokopiuk, Warszawa 1997, p. 456.

38 See A. Szyjewski, Etnologia, p. 89. M. Eliade wrote extensively about morphology and function of myths in Traktat o historii religii, trans. J. Wierusz-Kowalski, Warszawa 1966, pp. 403-429.

39 See B. Malinowski, O studiach, p. 144.

40 See W. Lengauer, Religijność, p. 21. 
theology of mysteries which attempts to explain and describe it. It is its creator, Odo Casel $(\dagger 1948)$, who explaining redemptive-historical meaning of the Mystery of Christ noticed that in ancient mystery religions every myth understood as a certain "truth"/"mystery" in the system of beliefs, which is worth emphasising, possessed its own ritual. Followers of a given religion believed that through an active participation in this ritual it is possible to enter into a relationship with deity which was evoked, recalled and objectively present. According to the participants of mystery religions each rite understood in this way was not only a repetition but also an "actualisation" and realisation of miraculous events from the lives of deities; it was a return, on the level of celebration, to primeval and established in mythologies times when "gods stayed among people."

Applying, on a formal level, the analogy to mysterious rituals but remembering about the fundamental difference, essential and substantive, between monotheism (especially Christianity) and other religions and beliefs it is possible to state that Christian liturgy is also a ritual action, entering and participation in the mystery of Christ (saying per analogiam participation in the Myth of Christ, in the most positive sense of the term "myth") and realisation of this Mystery through celebration. ${ }^{41}$

Streszczenie. Pojęcie „mitu” w historii, etnologii i fenomenologii religii. Termin „mit” zwykle bywa kojarzony ze światem nierealnym. Jest najczęściej rozumiany jako baśń, wymyślona historia, która nie ma nic wspólnego z rzeczywistością, i postrzegany jedynie jako wytwór ludzkiej fantazji. Wielu uczonych wskazuje na trwałość mitu w każdej kulturze, tak w literackiej kulturze piśmiennych społeczeństw greckich i rzymskich, jak i w wyłącznie ustnej tradycji niepiśmiennych społeczeństw pierwotnych. Fenomen trwałości mitu można zaś tłumaczyć szczególną jego funkcją i przypisywanym mu znaczeniem. Nietrudno też we wszystkich niemal wypadkach dostrzec związek mitu z obrzędem. Stosując na poziomie formalnym analogię do obrzędowości misterycznych i pamiętając o fundamentalnej różnicy, istotowej i merytorycznej, między monoteizmem (w szczególności chrześcijaństwem) i wszelkimi innymi religiami i wierzeniami, można powiedzieć, że liturgia chrześcijańska to także akcja rytualna, wchodzenie i uczestnictwo w Tajemnicy Chrystusa (mówiąc per analogiam, uczestnictwo w Micie Chrystusa, w jak najbardziej pozytywnym znaczeniu terminu „mit”) i urzeczywistnianie tej Tajemnicy poprzez celebrację.

Słowa kluczowe: mit; obrzęd; misterium; teologia misteriów; liturgia.

${ }^{41}$ See D. Brzeziński, "Chrystus wczoraj i dziś, i na wieki”, pp. 160-227. 
Abstract. The Notion of Myth in History, Ethnology and Phenomenology of Religion. No myth might be understood differently than as a vital cultural power. Thus no researcher can collect and analyse myths out of context. They must notice the influence of myth on social life, morality, law and also religious life with its entire rituals.

Many researchers demonstrate permanence of myths in every culture both in literary culture of literate Greek and Roman societies and in exclusively oral tradition of illiterate primeval communities. The phenomenon of permanence of myth might be explained by its special function and meaning. It is also not difficult to notice the relationship between myth and ritual in almost all cases.

Applying, on a formal level, the analogy to mysterious rituals but remembering about the fundamental difference, essential and substantive, between monotheism (especially Christianity) and other religions and beliefs it is possible to state that Christian liturgy is also a ritual action, entering and participation in the mystery of Christ (saying per analogiam participation in the Myth of Christ, in the most positive sense of the term "myth") and realisation of this Mystery through celebration.

Key words: myth; ritual; mystery; theology of mysteries; liturgy. 